Short communication

\title{
In-vitro virucidal activity of commercial enzyme preparations against SARS-CoV-2 virus
}

\author{
Anuradha V. Chitnis*, Abhijit K. Rathi
}

Advanced Enzymes Technologies Ltd. Thane

* Correspondence: anuradha@advancedenzymes.com

\begin{abstract}
Prevention practices have been extensively used to contain the spread of the SARS-CoV2 virus. These include social distancing, wearing masks, disinfection of hands, and sanitization of contact surfaces. However, the excessive usage of chemical disinfectants pose long term adverse effects to human health and the environment. Development of effective and environmentally friendly biocides, or virucidal agents, will help mitigate the ill effects of chemical disinfectants. Enzymes are potential candidates for the preparation of biocides against bacteria and viruses. Exploration of the virucidal activity of commercial enzymes, will highlight prospective, readily available sources for research on enzyme based biocides. In this study, the virucidal effect of some commercial enzyme preparations has been investigated against the SARS-CoV-2 virus. Vida Defense (2000 $\mu \mathrm{g} / \mathrm{ml})$, Excellacor $(1500 \mu \mathrm{g} / \mathrm{ml})$, and SEBkinase $(3000 \mu \mathrm{g} / \mathrm{ml})$ reduced SARS-CoV-2 viral titers by $\geq 1$ $\log$ CCID50 ( $\geq 90 \%)$. ImmunoSEB $(6000 \mu \mathrm{g} / \mathrm{ml})$ and Peptizyme SP $(500 \mu \mathrm{g} / \mathrm{ml})$ reduced the SARSCoV-2 viral titers by $0.8 \log$ CCID50 (84.2\%). The study indicates that enzyme preparations offer the potential to be explored further for an anti-viral biocide against SARS-CoV-2 for reducing the risk of COVID-19 transmission. However, further studies are mandated to improve efficacy and establish safety.
\end{abstract}

Keywords: SARS-CoV-2, enzymes, virucidal, biocide

\section{Introduction}

Coronaviruses have been a causative agent for serious and wide spread diseases, with the latest SARS-CoV-2 virus, causing a global pandemic. Coronaviruses are a large family of single-stranded RNA viruses (+ssRNA) that can be isolated in different animal species [1]. These viruses can cross species barriers and can cause illness ranging from the common cold to more severe diseases such as MERS and SARS, in humans [1]. At the moment, therapeutic interventions include management of symptoms. Prevention is the major strategy being practiced worldwide, due to absence of any licensed medicine for its cure. The SARS-CoV-2 is susceptible to ultraviolet rays and heat and can be effectively inactivated by lipid solvents including ether (75\%), ethanol, chlorine-containing disinfectant, peroxyacetic acid, and chloroform [2]. However, people have misused or excessively used disinfectants due to panic associated with COVID-2019. Many of these disinfectants have long-term adverse effects and may negatively impact human health and environment in the future [3]. 'Greener', enzyme based alternatives to chemical disinfectants have shown positive results [4]. Enzymes have been demonstrated to aid biofilm disruption caused by microorganisms in the food industry [5]. Several enzymes have demonstrated antimicrobial efficacy, and their safety and efficacy is recognized. There are also a few reports on the anti-viral effect of enzymes. Yamaguchi et al. [6] have explored the virucidal effects of glucose oxidase and peroxidase on HIV-type 1. Amtmann et al. [7] have demonstrated the virucidal effects of protease against koi herpesvirus and viral haemorrhagic 
septicaemia virus. Gudmundsdottir et al. [8], have reported a medical device mouth spray containing cod trypsin, a proteolytic enzyme, against the common cold. This enzyme preparation also inactivated the respiratory coronaviruses SARS-CoV-2 and HCoV-229E in vitro. Bacterial lipases from a Chromobacterium bacterium, named Chromobacterium antiviral effector-1 (CbAE-1) and CbAE-2, displayed a broad-spectrum invitro virucidal activity against dengue virus (DENV), Zika virus (ZIKV), severe acute respiratory syndrome coronavirus 2 (SARS-CoV-2), human immunodeficiency virus (HIV) and herpes simplex virus (HSV)[9]. In this paper we report the in vitro virucidal activity of commercially available enzyme preparations for SARS-CoV-2.

\section{Materials and Methods}

\subsection{Enzyme preparations}

Enzyme preparations were donated by Specialty Enzymes and Probiotics, Chino, CA. The enzymes included- a. Vida Defense-containing SEBPro VII Blend-(a blend of microbial and plant proteases), lysozyme, amylase, chitosanase, catalase and lipase enzymes. b. Excellacor- containing enteric coated serratiopeptidase, papain, bromelain, amylase, and lipase enzymes c. SEBkinase-containing enteric coated serratiopeptidase and nattokinase. d. Serratiopeptidase containing Peptizyme $\mathrm{SP}^{\mathrm{TM}}$ which is an enteric coated serratiopeptidase preparation and e. ImmunoSEB containing enzymes lysozyme, catalase, lactoperoxidase, Peptizyme SPTM (serratiopeptidase), bromelain, and lactoferrin.

\subsection{Laboratory}

Testing was carried out by an independent testing laboratory at The Institute for Antiviral Research (IAR), Utah State University

\subsection{Cells and virus strains}

SARS-CoV-2 (Isolate USA-WA1/2020), Source: World Reference Center for Emerging Viruses and Arboviruses, The University of Texas Medical Branch. Virus stocks were prepared by growing virus in Vero 76 cells (ATCC ${ }^{\circledR}$ CRL-1587 ${ }^{\mathrm{TM}}$ ). Test media used was MEM supplemented with $2 \%$ FBS and $50 \mu \mathrm{g} / \mathrm{mL}$ gentamicin.

The host cells used for the virucidal assay and culture media used was Vero E6 (ATCC ${ }^{\circledR}$ CRL-1586 ${ }^{\mathrm{TM}}$ ) in test media of minimum essential medium (MEM) supplemented with $2 \%$ fetal bovine serum (FBS) and $50 \mu \mathrm{g} / \mathrm{ml}$ gentamicin.

\section{Viral deactivation test}

Samples were reconstituted in distilled water to prepare test concentrations as given below. ImmunoSEB was tested at 600 and $6000 \mu \mathrm{g} / \mathrm{ml}$, SEBkinase was tested at 300 and 3000 $\mu \mathrm{g} / \mathrm{ml}$, Vida Defense was tested at 50 and $500 \mu \mathrm{g} / \mathrm{ml}$, Excellacor was tested at 150 and 1500 $\mu \mathrm{g} / \mathrm{ml}$, Serratiopeptidase was tested at 50 and $500 \mu \mathrm{g} / \mathrm{ml}$. SARS-CoV-2 virus stock was added to triplicate tubes of each prepared concentration so that there was $50 \%$ virus solution by volume and $50 \%$ prepared sample. Media only was added to one tube of each prepared concentration to serve as toxicity controls. Ethanol was tested in parallel as a positive control and distilled water only to serve as the virus control. Compound and virus were incubated at $37^{\circ} \mathrm{C}$ for a 30 minute contact period. Following the contact period, the solutions were neutralized by a $1 / 10$ dilution in test media. 


\subsection{Virus quantification}

Surviving virus was quantified by standard end-point dilution assay. Neutralized samples were combined for quantification for the average of triplicate tests. Samples were serially diluted using eight 10 -fold dilutions in test medium. Each dilution was added to 4 wells of a 96-well plate with $80-100 \%$ confluent Vero E6 cells. The toxicity controls were added to an additional 4 wells and 2 of these wells were infected with virus to serve as neutralization controls, ensuring that residual sample in the titer assay plated did not inhibit growth and detection of surviving virus. Plates were incubated at $37 \pm 2{ }^{\circ} \mathrm{C}$ with $5 \%$ $\mathrm{CO} 2$. On day 6 post-infection plates were scored for presence or absence of viral cytopathic effect (CPE). The Reed-Muench method [10] was used to determine end-point titers (50\% cell culture infectious dose, CCID50) of the samples, and the log reduction value (LRV) of the compound compared to the negative (water) control was calculated. The percent inactivation was calculated using the formula $\left(1\left(1 / 10^{\mathrm{LRV}}\right)\right.$ X100 \% where LRV is the $\log$ reduction value.

\subsection{Controls}

Virus controls were tested in water and the reduction of virus in test wells compared to virus controls was calculated as the log reduction value (LRV). Toxicity controls were tested with media not containing virus to see if the samples were toxic to cells. Neutralization controls were tested to ensure that virus inactivation did not continue after the specified contact time, and that residual sample in the titer assay plates did not inhibit growth and detection of surviving virus. This was done by adding toxicity samples to titer test plates then spiking each well with a low amount of virus that would produce an observable amount of CPE during the incubation period.

\section{Results}

Virus titers and log reduction values (LRV) against SARS-CoV-2 are shown in Table 1. The average virus control titer was $5.3 \log$ CCID50 per $0.1 \mathrm{ml}$ and this was used for comparison of all test sample titers to determine LRV. The limit of detection of virus for samples that did not exhibit cytotoxicity when plated for endpoint dilution assay was 0.7 $\log$ CCID50 per $0.1 \mathrm{ml}$. Vida Defense $(2000 \mu \mathrm{g} / \mathrm{ml})$, Excellacor $(1500 \mu \mathrm{g} / \mathrm{ml})$, and SEBkinase $(3000 \mu \mathrm{g} / \mathrm{ml})$ reduced SARS-CoV-2 by $\geq 1$ log CCID50 ( $\geq 90 \%)$. ImmunoSEB $(6000 \mu \mathrm{g} / \mathrm{ml})$ and Serratiopeptidase $(500 \mu \mathrm{g} / \mathrm{ml})$ reduced the viral titer of SARS-CoV-2 by $\geq 0.8 \log$ CCID50 ( $\geq 84.2 \%$ ). Vida Defense particularly was able to reduce the SARS-CoV2 by $1.3 \log$ CCID50 (95\%), within the contact time of 30 minutes. Full cytotoxicity (>80\%) was not observed with any of the tested samples. Neutralization controls demonstrated that residual sample did not inhibit virus growth and detection in the endpoint titer assays in wells that did not have cytotoxicity. For the reference product control, 95\% ethanol was used as a test substance which showed a log reduction of $\geq 4.6$ for SARS-CoV-2 (Table 1). All the controls met the criteria for a valid test.

Table 1. Virucidal efficacy of enzyme preparations against SARS-CoV-2 after incubation with virus

\begin{tabular}{|l|c|c|c|c|c|}
\hline Sample & $\begin{array}{c}\text { Concentra- } \\
\text { tion } \\
(\mu \mathrm{g} / \mathrm{ml} \mathbf{)}\end{array}$ & $\begin{array}{c}\text { Virus } \\
\text { Titer }^{\mathbf{a}}\end{array}$ & $\begin{array}{c}\text { VC } \\
\text { Titer }^{\mathbf{a}}\end{array}$ & LRV $^{\mathbf{b}}$ & $\begin{array}{c}\text { Percent } \\
\text { inactivation }\end{array}$ \\
\hline Serratiopeptidase & 500 & 4.5 & 5.3 & 0.8 & 84.2 \\
\hline Serratiopeptidase & 50 & 5.5 & 5.3 & 0 & 0.0 \\
\hline
\end{tabular}




\begin{tabular}{|l|c|c|c|c|c|}
\hline Vida Defense & 2000 & 4 & 5.3 & 1.3 & 95.0 \\
\hline Vida Defense & 200 & 4.5 & 5.3 & 0.8 & 84.2 \\
\hline Excellacor & 1500 & 4.3 & 5.3 & 1 & 90.0 \\
\hline Excellacor & 150 & 4.7 & 5.3 & 0.6 & 74.9 \\
\hline SEBKinase & 3000 & 4.3 & 5.3 & 1 & 90.0 \\
\hline SEBKinase & 300 & 4.5 & 5.3 & 0.8 & 84.2 \\
\hline ImmunoSEB & 6000 & 4.5 & 5.3 & 0.8 & 84.2 \\
\hline ImmunoSEB & 600 & 4.7 & 5.3 & 0.6 & 74.9 \\
\hline Ethanol & $95 \%$ & $<0.7$ & 5.3 & $>4.6$ & $>99.99$ \\
\hline
\end{tabular}

${ }^{a}$ virus titer of test sample or virus control (VC) in $\log _{10} C_{C} I_{50}$ of virus per $0.1 \mathrm{ml}$

b LRV (log reduction value) is the reduction of virus in test sample compared to virus control

\section{Discussion}

The study described in this paper is one of the few to investigate the virucidal effect of enzymes on SARS-CoV-2. Based on the results presented in this study, Vida Defense, Excellacor and SEBkinase inactivated SARS-CoV-2 by $\geq 90 \%$ within a contact time of 30 minutes. No cytotoxicity was observed for the concentrations of enzymes tested. ImmunoSEB and Serratiopeptidase inactivated SARS-CoV-2 by $\geq 84.2 \%$. The viral titer reductions are indicative of virucidal activity of the enzymes. Serratiopeptidase is a single enzyme protease preparation. Serratiopeptidase has been previously shown to be effective for biofilm reduction [11]. The rest of the enzyme preparations are multi-enzyme preparations. Serratiopeptidase at a dosage of $500 \mu \mathrm{g} / \mathrm{ml}$ gave a percent inactivation of $84.2 \%$, whereas Vida Defense gave the same percent inactivation at a dosage of $200 \mu \mathrm{g} / \mathrm{ml}$. This indicates better viral inactivation by multi-enzyme preparation of Vida Defense compared to single enzyme Serratiopeptidase, which also shows promising results. SEBkinase contains nattokinase in addition to serratiopeptidase. SEBkinase gave a percent inactivation of $84.2 \%$ at a dosage of $300 \mu \mathrm{g} / \mathrm{ml}$, showing a better viral inactivation by combination of nattokinase and serratiopeptidase than serratiopeptidase alone. A higher dosage of $3000 \mu \mathrm{g} / \mathrm{ml}$ of SEBkinase gave a greater inactivation of $90 \%$. ImmunoSEB has demonstrated a maximum percent inactivation of $84.2 \%$ at dosage of $6000 \mu \mathrm{g} / \mathrm{ml}$. This is indicative of its virucidal properties. ImmunoSEB has shown antibacterial activity and antifungal activity in previous in-vitro studies $[12,13]$.

These results demonstrate that enzymes can be effective as virucidal agents, opening a possibility of the application of the tested enzymes for the inactivation of SARS-CoV-2. However, the formulation of the preparations tested need to be further optimized to be increase the percent inactivation to higher than $99.99 \%$. Coronaviruses are enveloped, positive-stranded RNA viruses. Various proteins and glycoproteins form structural elements in envelop and nucleocapsid [14]. Coronaviruses are surrounded by a fatty layer, called a "lipid envelope," into which the spike glycoprotein receptors are embedded. A well-documented virucidal strategy includes the interfering with the lipid envelop is against many coronaviruses. The impact of many agents using this strategy has been highlighted by O'Donnell et al. [15]. These include soap and $60 \%-70 \%$ alcohol-based gels [15]. The enzyme preparations used for this study contain proteases and lipases as major components, in addition to other enzymes. Proteases and lipases from other sources have demonstrated virucidal effects in previous studies $[6,7,8,9]$. The mechanism of inactivation of the virus under study could be mediated by the catalytic action of the enzymes on the virion structure or the disruption of the receptors used for gaining entry into the host cell. 
The results of this study opens up possibilities in the usage of commercial enzymes for making sustainable and environmentally friendly biocides. Enzymes, especially containing lipases and proteases can be included in products meant for disinfecting surfaces, in oral rinses or oral spray products. Synergistic combinations of enzymes with chemical disinfectants enabling high efficacy, better safety for humans and better compatibility with the environment can also be sought. There is an urgent need for further exploring enzymes in virucidal applications with this perspective.

Supplementary Materials: NA.

Author Contributions: Anuradha Chitnis designed the experiments, prepared and edited the manuscript. Abhijit Rathi contributed to the design of the experiments, reviewed, and approved the manuscript. All authors have read and agreed to the published version of the manuscript.

Funding: This study was funded by Specialty Enzymes and Probiotics, Chino, CA.

Data Availability Statement: The data presented in this study is available on reasonable request from the corresponding author.

Acknowledgments: Authors are grateful to Mr. V.L. Rathi, and Mr. Ankit Rathi, at Specialty Enzymes and Probiotics for supporting the study. The authors also thank Dr. Swati Jadhav at Advanced Enzyme Technologies Ltd., for her advice and inputs.

Conflicts of Interest: The authors declare no conflict of interest. The funder had no role in the design of the study; in the collection, analyses, or interpretation of data; or in the writing of the manuscript.

\section{References}

1. Cascella, M.; Rajnik M, Cuomo, A.; Dulebohn, S.C; Napoli, R.D. Features, evaluation, and treatment of Coronavirus. StatPearls [Internet] 2020, Treasure Island (FL): StatPearls Publishing; Available online: https://www.ncbi.nlm.nih.gov/books/NBK554776/ accessed on 17 December 2020

2. Hancu, A.; Mihaltan, F. Possible nutritional interventions in COVID 19. Maedica (Bucur) 2020, 15(2), $246-249$. doi:10.26574/maedica.2020.15.2.246

3. Rai, N.K.; Ashok, A.; Akondi, B.R. Consequences of chemical impact of disinfectants: safe preventive measures against COVID-19. Crit Rev Toxicol. 2020, 50(6), 513-520. doi: 10.1080/10408444.2020.1790499

4. Augustin, M.; Ali-Vehmas, T.; Atroshi, F. Assessment of enzymatic cleaning agents and disinfectants against bacterial biofilms. J Pharm Pharm Sci. 2004 7(1), 55-64.

5. Gutiérrez, T. J. (). Antibiofilm Enzymes as an emerging technology for food quality and safety. In Enzymes in food biotechnology: Production, applications, and future prospects, Kuddus, M., Eds; Academic Press: London, 2019, pp. 321-342. doi:https://doi.org/10.1016/B978-0-12-813280-7.00019-0.

6. Yamaguchi, Y.; Semmel, M.; Stanislawski, L.; Strosberg, A.D.; Stanislawski, M. Virucidal effects of glucose oxidase and peroxidase or their protein conjugates on human immunodeficiency virus type 1. Antimicrob Agents Chemother. 1993, 37(1), 26-31. doi:10.1128/aac.37.1.26

7. Amtmann, A.; Ahmed, I.; Zahner-Rimmel, P; Mletzko, A; Jordan, L.K.; Oberle, M.; Wedekind, H.; Christian, J.; Bergmann, S.M.; Becker, A.M. Virucidal effects of various agents-including protease-against koi herpesvirus and viral haemorrhagic septicaemia virus. J Fish Dis. 2020, 43(2), 185-195. doi: 10.1111/jfd.13106.

8. Gudmundsdottir, Á.; Scheving, R.; Lindberg, F.; Stefansson, B. Inactivation of SARS-CoV-2 and HCoV-229E in vitro by ColdZyme ${ }^{\circledR}$ a medical device mouth spray against the common cold. J Med Virol. 2020. 1-4.

9. Yu, X.; Zhang, L.; Tong ,L.; Zhang, N.; Wang, H.; Yang, Y.; Shi, M.; Xiao, X; Zhu, Y.; Wang, P.; Ding, Q.; Zhang, L.; Qin, C.; Cheng, G. Broad-spectrum virucidal activity of bacterial secreted lipases against flaviviruses, SARS-CoV-2 and other enveloped viruses. bioRxiv, 2020. doi: 10.1101/2020.05.22.109900.

10. Reed, L.; Muench, H. A simple method of estimating fifty per cent endpoints, Am. J. Epidemiol. 1938, 27(3), 493-497, https://doi.org/10.1093/oxfordjournals.aje.a118408

11. Jadhav, S.B.; Shah, N.; Rathi, A.; Rathi, V.; Rathi, A. Serratiopeptidase: Insights into the therapeutic applications. Biotechnol Rep (Amst). 2020, 28:e00544. doi: 10.1016/j.btre.2020.e00544.

12. Joshi, A., Shahane, V., Gore, V., Kagal, A., Risbud, S., \& Bharadwaj, R. In vitro evaluation of antibacterial activity of a novel polyenzyme preparation Immunoseb. Trends in Biosciences 2013, 6(2), 142-145. Available online: http://trendsinbiosciencesjournal.com/archives/TsOVhVATe0X3mkAUiFn73OxdkphBQsmroafNtsIqTnEEk2nAcOSzzitnjB.vaArC9HjX 6zZ0vzdKjdR0sg87w-- accessed on 17 December 2020. 
13. Joshi, A.; Deshpande, S.; Dohe, V.; Risbud, S.; Bharadwaj, R., Screening for antifungal activity of polyenzyme preparation ImmunoSEB ${ }^{\mathrm{TM}}-\mathrm{S}$ using in vitro methods. Trends in Biosciences 2013, 6 (3), 234- 236. Available online: http://trendsinbiosciencesjournal.com/article/KNdDyf9ZgtmUqtk.ksk8AuADxtdFF4TWKw11LZt5X3sn0VsnNbQR.jBFclgbIEoJgtvwD4q3dp1X3AUrAwg Kg-- accessed on 17 December 2020.

14. Astuti, I.; Ysrafil. Severe Acute Respiratory Syndrome Coronavirus 2 (SARS-CoV-2): An overview of viral structure and host response. Diabetes Metab Syndr. 2020, 14(4), 407-412. doi:10.1016/j.dsx.2020.04.020

15. O'Donnell, V.B.; Thomas, D.; Stanton, R, Valerie B O’Donnell, David Thomas, Richard Stanton, Maillard, J.; Murphy, R.C.; Jones, S.A.; Humphreys, I.; Wakelam, M.J.O.; Fegan, C.; Wise, M.P.; Bosch A.; Sattar, S.A. Potential Role of oral rinses targeting the viral lipid envelope in SARS-CoV-2 infection. Function 2020, 1(1), zqaa002. doi:10.1093/function/zqaa002 